Çukurova Üniversitesi Mühendislik Mimarlık Fakültesi Dergisi, 33(2), ss. 177-188, Haziran 2018

Çukurova University Journal of the Faculty of Engineering and Architecture, 33(2), pp. 177-188, June 2018

\title{
Narlı Kumunun Üç Eksenli Kayma Davranışı
}

\author{
Zuheir KARABASH ${ }^{1}$, Ali Fırat ÇABALAR ${ }^{* 2}$, Süleyman DEMİR \\ ${ }^{1}$ Musul Üniversitesi, Mühendislik Fakültesi, Baraj ve Su Kaynakları Bölümü, Musul \\ ${ }^{2}$ Gaziantep Üniversitesi, Mühendislik Fakültesi, İnşaat Mühendisliği Bölümü, Gaziantep \\ ${ }^{3}$ Kilis 7 Aralı Üniversitesi, Mühendislik Fakültesi, Mimarlık Bölümü, Kilis
}

Geliş tarihi: 27.11.2017 Kabul tarihi: 29.06.2018

\section{$\ddot{O} z$}

Bu çalışmada, Güneydoğu Anadolu Bölgesi’nin batısındaki altyapı inşaat faaliyetlerinde sıklıkla kullanılan Narlı Kumuna ait kayma davranışını araştırmak için yapılan üç eksenli basınç deneyi sonuçları sunulmaktadır. Üç farklı efektif gerilme $(50 \mathrm{kPa}, 100 \mathrm{kPa}$, ve $150 \mathrm{kPa})$ ve iki farklı konsolidasyon süresinin (3 saat, ve 18 saat) kayma davranışına etkisi konsolidasyonlu-drenajlı (CD) ve konsolidasyonludrenajsız (CU) deneylerle araştırılmıştır. Çalışmada, Narlı Kumuna ait üç farklı rölatif sıkılıktaki (gevşek, orta sıkı, sık1) kayma davranışı da sunulmaktadır. Araştırmacılar ve arazide çalışan mühendislerin kullanımı için sunulan deney sonuçları, Narlı Kumuna ait kayma mukavemeti ve rijitlik değerlerinin efektif gerilme, konsolidasyon süresi, ve rölatif sıkılık değerlerindeki artışa bağlı olarak arttığını göstermiştir. Ayrıca, CD şartları altında test edilen örneklere ait deviatörik gerilme, rijitlik, ve içsel sürtünme açısı değerlerinin CU şartlarında test edilen aynı numunelere göre daha yüksek olduğu gözlemlenmiştir.

Anahtar kelimeler: Narlı kumu, Üç eksenli test, Rölatif sıkılık, Konsolidasyon süresi

\section{Triaxial Shear Behavior of Narlı Sand}

\begin{abstract}
This study presents an intensive series of conventional triaxial compression tests conducted to investigate the shear behavior of Narli sand, which is a widely consumed geomaterial in earthwork projects in the southern central of Turkey. The effect of three different effective confining pressures $(50 \mathrm{kPa}, 100 \mathrm{kPa}$, and $150 \mathrm{kPa}$ ) and two consolidation periods ( $3 \mathrm{hrs}, 18 \mathrm{hrs}$ ) were investigated during the both consolidated drained (CD) and consolidated undrained (CU) tests. The study also presents the effect of different relative densities (loose, medium, and dense state of the sand) to the shear response of Narli sand. Test results, which are presented for further use by researchers and engineers in practice, indicated that the shear strength and stiffness of Narli sand increase as the effective confining pressure, consolidation period, and the relative density values increase. Further, Narli sand tested in the CD condition exhibits deviatoric stress, stiffness, angle of internal friction values higher than their values observed in the CU condition.
\end{abstract}

Keywords: Narli sand, Triaxial test, Relative density, Consolidation period

*Sorumlu yazar (Corresponding author): Ali Firat ÇABALAR, cabalar@gantep.edu.tr 


\section{GíRiș}

Zeminlerin kayma mukavemetini belirlemek için yapılan araştırmalar 1776'da Coulomb [1] tarafından yapılan teorik çalışmalara kadar uzanmaktadır. Zeminlerin üç eksenli yükleme altındaki gerilme-şekil değiştirme davranışları geoteknik mühendisliğindeki analizler için çok önemlidir. Kum örneklerinin üç eksenli kayma davranışı hücre basınc1, doygunluk derecesi, drenaj koşulları, rölatif sıkılık, dane şekli ve büyüklüğü gibi değerlerden önemli oranda etkilenmektedir [2-13]. Örneğin, farklı hücre basınçları altındaki zeminlerin gerilme-şekil değiştirme davranışlarını inceleyen Ahmed [3] ve Sayeed ve arkadaşları [7], düşük basınçlar altındaki ayrışma ve sıkışabilirliliğin daha fazla olduğunu göstermiştir. Porovir ve Jardine [14], ve Viggiani ve Atkinson [15] bir zemin örneğinin rijitliği ile ortalama efektif gerilme arasındaki değișime işaret ederek, bu değişimin büyük şekil değiştirme oranlarında lineer olduğunu belirtmişlerdir. Clayton ve Heymann [8] örselenmemiş kil örneklerine ait maksimum rijitlik değerlerinin ortalama efektif gerilmeye bağlı olarak değiştiğini göstermiştir. Kramer ve Seed [4], ve Della ve arkadaşları [6] sıvılaşma riskinin artan hücre basıncı ve rölatif sıkılıkla azaldığına işaret etmişlerdir. Yapılan araştırmalarda, rölatif sıkılık değerlerinin içsel sürtünma açısı ve kayma mukavemeti üzerinde de oldukça etkili olduğu gözlemlenmiştir [16-18]. Hücre basıncı ile değiştiği bilinen drenajsız kayma mukavemeti değerleri ise drenajlı deney koşullarında elde edilen mukavemet değerlerine kıyasla çok daha fazla olmaktadır [19-22].

Bu çalışmada, Kahramanmaraş'ın Pazarcık ilçesine bağlı Narlı beldesi boyunca akan Aksu Çayı kıyısından elde edilen 'Narlı Kumu' örneklerine ait üç eksenli basınç altındaki kayma davranışı sunulmaktadır. Aksu Çayı Kahramanmaraş'ın kuzeydoğusundaki Engizek Dağ $1 \quad\left(37^{\circ} 36^{\prime} \mathrm{K} ; 36^{\circ} 55^{\prime} \mathrm{D}\right)$ eteklerindeki karstik kaynaklardan doğarak Ceyhan Nehriyle birleşir. Narlı Kumu, ülkemizin bu bölgesinde yeralan ve hızla gelişen Adana, Gaziantep, Antakya, Mersin, Kahramanmaraş, Osmaniye ve Kilis gibi şehirlerimizdeki altyapı inşaat faaliyetlerinde sıklıkla kullanılmaktadır. Ancak, bir zemin malzemesi olarak kullanılan bu kuma ait mekanik özellikler henüz araştırılmamıştır. Bu nedenle, bu çalışmada çeşitli şartlar (farklı hücre basıncı, konsolidasyon süresi, rölatif sıkılık, ve drenaj koşulu) altındaki Narlı Kumuna ait üç eksenli kayma davranışına dikkat çekilmektedir.

\section{DENEYSEL CALISYMA}

\subsection{Kullanılan Malzeme}

Deneysel çalışmada kullanılan Narlı Kumu örnekleri Kahramanmaraş'taki Aksu Çayı kıyısından elde edilen yuvarlak şekil özelliğine sahip dere kumudur. Kum örnekleri, test edilmeden önce 0,3-1,0 $\mathrm{mm}$ aralığında kalacak şekilde elenerek yıkandıktan sonra $100 \pm 5 \mathrm{C}^{\circ}$ 'de kurutulmuştur (Şekil 1).

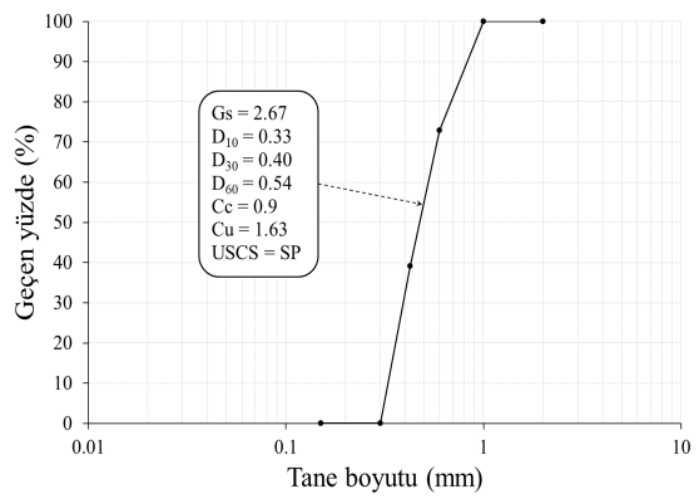

Şekil 1. Narlı kumuna ait elek analizi

Kullanılan kum örneklerine ait $\mathrm{D}_{10}, \mathrm{D}_{30}$, ve $\mathrm{D}_{60}$ değerleri sirasiyla $0,33,0,40$, ve 0,54 olarak tespit edilmiştir. Böylece, üniformluluk katsayısı $\left(\mathrm{c}_{\mathrm{u}}\right)$ ve eğrilik katsayısı $\left(c_{c}\right)$ değerleri sırasıyla 1,63 ve 0,9 olarak hesapland. Birleştirilmiş zemin siniflandirma sistemine göre yapılan sınıflandırmada, deneylerde kullanılan örnekler kötü derecelendirilmiş kum (SP) olarak sınıflandırılmıştır. Özgül ağırlığı, en az ve en fazla kuru birim hacim ağırlığ değerleri sırasıyla 2,67, $1,44 \mathrm{~cm}^{3}$, ve $1,71 \mathrm{~g} / \mathrm{cm}^{3}$ olan kum örneklerine ait taramalı elektron mikroskop (TEM) resimleri Şekil 2'de sunulmaktadır. 


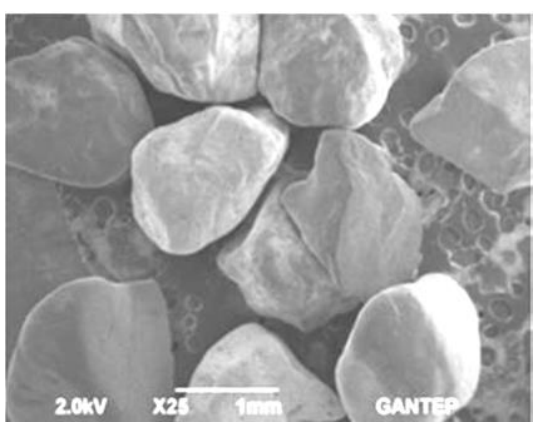

Şekil 2. Narlı kumuna ait taramalı elektron mikroskobu (TEM) görüntüsü.

\subsection{Numunelerin Hazırlanması}

Test edilen tüm üç eksenli deney numuneleri 70 $\mathrm{mm}$ çapında ve $140 \mathrm{~mm}$ yüksekliğindedir. Deney için ilk olarak filtre kağıdı taban kaidesine yerleştirildi, daha sonra numuneye su girmemesi için dış kısma su geçirmez membran konulmuş ve halka iteceği kulanılarak iki adet O-halkası takılmıştır. İçerisinde numunelerin hazırlandığ $\mathrm{iki}$ parçalı kalıp, numunenin şeklini koruması için taban kaidesine yerleştirilmiş ve iki parçalı kalıp ile membran arasına vakum (negatif basınç) uygulanmıştır. Önceden hesaplanan rölatif sıkılık değeri dikkate alınarak kullanılacak kum miktarı hesaplandı. Daha sonra ağırlığı bilinen kum örneği, alt ucu kalıbın içine uzanan geniş bir ağızlı huni yardımıyla ince tabakalar halinde yerleştirilmiştir. Herbir tabaka gerek görülmesi halinde vibrasyon uygulayarak sıkıştırılmışıtır. Gerekli miktarda kumu kalıba yerleştirmek için, kumun rölatif sıkıllı̆̆ arttıkça uygulanan vibrasyon enerjisi de arttırılmıştır. Kalıp tamamiyle dolduğunda kalıbın üst yüzeyi spatula ile düzeltildikten sonra numunenin üst yüzeyi bir filtre kağıdıyla kapatılmış ve üst başlık iki Ohalkası yardımıla membranın üzerine yerleştirilmiştir. Hazırlanan numunenin altından üste doğru su çevrimi yapılarak zemin örneği doygun hale getirilmiştir. Bu çevrim sırasında suyun sabir hızda akışını sağlamak için yaklaşık 10 $\mathrm{kPa}$ vakum uygulanmıştır. Boşluksuyu basıncı -10 $\mathrm{kPa}$ 'da sabitlendikten sonra, iki parçalı kalıp dikkatli bir şekilde kaldırılmıştır. Hazırlanan numune üzerinde üç farklı noktada numune çapı (alt, orta, üst) ve yüksekliği ölçülerek ortalama değerler elde edilmiştir. Daha sonra üç eksenli deney hücresi su ile doldurulmuştur. Yanal su basınc1 aşamalı olarak artırılırken, numune içindeki boşluk suyu basıncı da istenilen seviyeye ulaşıncaya kadar (örneğin $400 \mathrm{kPa}$ boşluk suyu basınc1 ve $500 \mathrm{kPa}$ hücre basıncı) artırılmıştır. İlk grup numuneler bu basınçlar altında 18 saat konsolidasyonda bırakılmışırı. İkinci grup numuneler 3 saat konsolidasyonda bırakılmış, ve bekleme sonrasinda B doygunluk katsayısı [23] belirlenmiştir. Son olarak, hazırlanan numunelere ait kayma mukavemeti uygulanan düşey kuvvet yardımıyla tespit edilmiştir. Numune hazırlanması süresinde takip edilen adımlar farklı sıkılıktaki numuneler için aynen uygulanmıştır.

\subsection{Deney Yöntemi}

Deneyler $50 \mathrm{kN}$ kapasiteli ELE marka üç eksenli yükleme çerçevesinde yapıldı. Deney ekipmanı 4,5 kN'luk yükleme hücresi, iki adet $1000 \mathrm{kPa}$ kapasitesli basınç ölçer (boşluk suyu basıncı ve hücre basıncı için), ve $25 \mathrm{~mm}$ ölçüm kapasitesine sahip şekil değiştirme sensörü ile donatılmıştır.

Konsolidasyonlu-drenajlı (CD) ve konsolidasyonlu -drenajsız (CU) testler önceki bölümde anlatılan basamaklara göre hazırlanmış kum numuneleri üzerinde gerçekleştirilmiştir. Çalışmadaki testler tam doygun Narlı Kumu örnekleri üzerinde uygulanmıştır. Test edilen tüm numuneler 450 $\mathrm{kPa}, 500 \mathrm{kPa}$, veya $550 \mathrm{kPa}$ hücre basinc1 ile 400 $\mathrm{kPa}$ boşluk suyu basınç değerleri altında konsolidasyona bırakılmışlardır. Konsolidasyon sonrasinda, drenajsız testler sirasında drenaj vanası kapalı tutulurken, drenajlı testlerde açık bırakılmıştır. Drenajsız testlerde $0,1 \mathrm{~mm} / \mathrm{dk}$, drenajlı testlerde ise $0,05 \mathrm{~mm} / \mathrm{dk}$ düşey yükleme hızı uygulanmıştır. Deneyler sırasında elde edilen deviatörik gerilme, eksenel şekil değiştirme, boşluksuyu basıncı, ve hacim değişimi ölçümleri her 10 saniyede bir kaydedilmiştir.

\section{BULGULAR VE TARTIŞMA}

Temiz Narlı kumu örneklerinin farklı koşullardaki (hücre basınc1, konsolidasyon süresi, rölatif sıkılık, drenaj) kayma davranışını incelemek amacıyla üç eksenli basınç ekipmanında yoğun bir deneysel çalışma programı takip edilmiştir. Daha önceki 
bölümlerde açıklanan yöntemlere göre hazırlanan ve konsolide süresi sonunda test edilen numuneler için iki grup üç eksenli basınç deneyleri yapılmıştır. Birinci grup üç eksenli basınç deneyleri konsolidasyonlu-drenajsız (CU), ikinci grup deneyler ise konsolidasyonlu-drenajlı (CD) koşullar altında gerçekleştirilmiştir. Her deney serisi $50 \mathrm{kPa}, 100 \mathrm{kPa}$ ve $150 \mathrm{kPa}$ efektif gerilme altında ve 3 saat veya 18 saat konsolidasyon süresini takiben tamamlanmıştır.

Birinci grup (CU) deneylerde test edilen örnekler gevşek bir sıkılıkta (\%35) hazırlanmışlardır [24]. Şekil 3'te üç farklı efektif gerilme ve iki farklı konsolidasyon süresi için deviatörik gerilmeeksenel şekil değiştirme, ve boşluk suyu basınc1eksenel şekil değiştirme ilişkileri sunulmaktadır. Görüldüğü üzere, ölçüm yapılan aralıkta, deviatörik gerilme artan eksenel şekil değiştirme ile birlikte artmıştır.
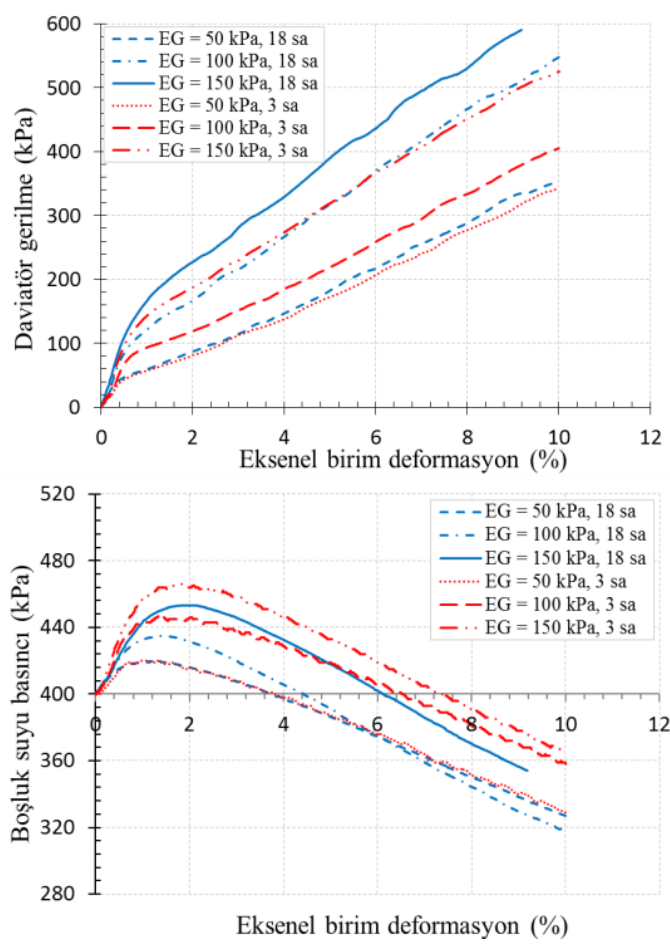

Şekil 3. CU deney koşullarında 3 ve 18 saat konsolidasyon sürelerinde test edilen Narlı kumuna ait (a) gerime-şekil değiştirme eğrisi (b) boşluk suyu basınc1-eksenel birim deformasyon eğrisi
Ayrıca, aynı aralıktaki boşluk suyu basıncı değerlerinin artan efektif gerilme ile birlikte arttığ gözlemlenmiştir. Buna ilaveten, hücre basıncı ve konsolidasyon süresinden bağımsız olarak, tüm testlerde eksenel şekil değiştirme arttıkça zemin sertleşmesi gözlemlenmiştir. Diğer taraftan, uygulanan tüm hücre basıncı değerlerinde $(50 \mathrm{kPa}$, $100 \mathrm{kPa}, 150 \mathrm{kPa}$ ), artan konsolidasyon süresiyle deviatörik gerilme değerlerinde \%7 ile \%25 arasındaki oranlarda artış, ve boşluk suyu basıncı değerlerinde ise $\% 5$ ile $\% 8$ arasındaki oranlarda azalma görülmüştür. Düşük hücre basınc1 değerlerinde $(50 \mathrm{kPa})$ konsolidasyon süresinin çok daha az etkili olmuştur. Hücre basıncı arttıkça, deviatörik gerilme ve en fazla kayma dayanımı artmıştır. Ulaşılan bu sonuçlar Della ve arkadaşları [6], ve Park ve Jeong [22] ile uyumluluk göstermektedir.

Üç farklı hücre basıncı ve iki farklı konsolidasyon süresinde test (CU) edilen temiz kum örneklerine ait gerilme izi değişimleri Şekil 4'de gösterilmektedir.

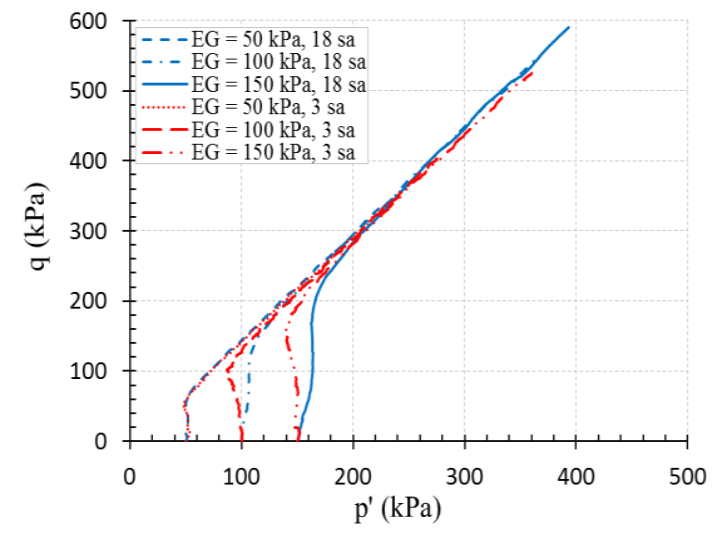

Şekil 4. CU deney koşullarında 3 ve 18 saat konsolidasyon sürelerinde test edilen Narlı kumuna ait gerilme izi

$\mathrm{Bu}$ grafikteki q değeri deviatörik gerilmeyi, p' ise ortalama efektif gerilmeyi ifade eder. Aynı renkteki gerilme izi değerleri (kırmızı ya da mavi), hücre basıncındaki değişimlerin kum numunelerinin hacimsel genleşme ve büzülme davranışları üzerinde önemli bir etkiye sahip olmadığını net bir şekilde göstermektedir. Zira, Şekil 4'te kırmızı ya da mavi renkle gösterilen 
gerilme izi değerleri arasında büyük bir paralellik olduğu görülmektedir. Ayrıca efektif gerilme değeri arttıkça, konsolidasyon süresinin gerilme izi sonuçları üzerinde etkisi artmaktadır. Örneğin, $50 \mathrm{kPa}$ efektif gerilme altında farklı konsolidasyon süreleri sonunda test edilen numunelerin aynı gerilme izi değerlerini vermesine rağmen, $100 \mathrm{kPa}$ ve $150 \mathrm{kPa}$ efektif gerilme değerleri altında farklı konsolidasyon süreleri sonunda test edilen numunelerin oldukça farklı gerilme izi değerleri verdiği görülmektedir. Hatta, uzun süreli konsolidasyona birakılan numunelerin hacimsel ayrışma (dilatation), kısa süreli konsolidasyona bırakılan numunelerin ise hacimsel azalma (contraction) sergilediği tespit edilmiştir. Test edilen örnekler düşük konsolidasyon sürelerinde daha fazla hacimsel azalma göstermektedirler. Bu davranışın deney sırasında oluşan aşırı boşluk suyu basıncından kaynaklandığı düşünülmektedir.

Şekil 5 farklı efektif gerilme ve konsolidasyon süreleri altında konsolide edildikten sonra test edilmiş örneklere ait rijitlik ve eksenel şekil değiştirme ilişkisini göstermektedir.

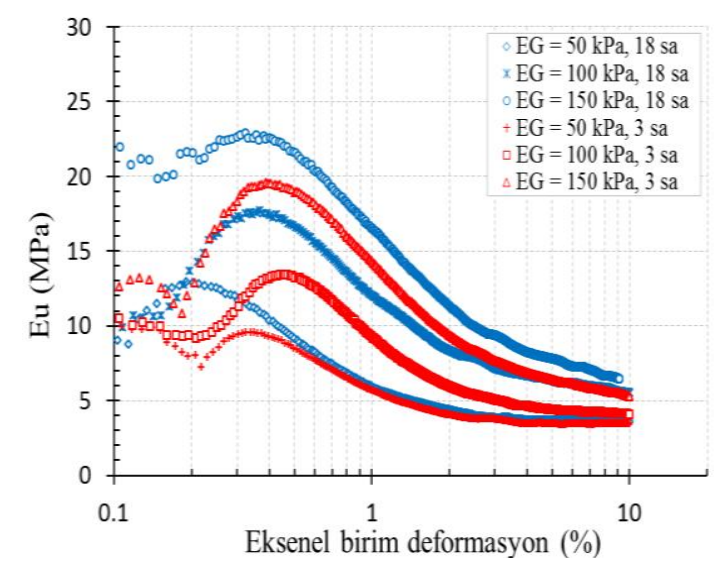

Şekil 5. CU deney koşullarında 3 ve 18 saat konsolidasyon sürelerinde test edilen Narlı kumuna ait elastisite modülü değerlerinin karşılaştırılması

Genel olarak bakıldığında, eksenel şekil değiştirme arttıkça zeminin rijitliği bozulmaya uğramıştır. Yüksek hücre basıncında konsolide edilerek test edilmiş temiz kum örnekleri, düşük hücre basıncındakine göre daha fazla rijitliğe sahiptir. $\mathrm{Bu}$ davranış, efektif gerilmedeki artışa bağlı olarak oluşan kum taneleri arasındaki temas alanı ve içsel sürtünme açısının artmasıyla açıklanabilir. Diğer yandan, daha uzun süre (18 saat) konsolidasyona maaruz birakılan örnekler, daha az konsolidasyonda (3 saat) kalan örneklere göreceli olarak daha yüksek rijitlik göstermiştir. Fakat hücre basıncı azaldıkça $(50 \mathrm{kPa})$, konsolidasyon süresinin etkisi de azaldığ gözlemlenmektedir.

İkinci grup üç eksenli basınç deneyleri (CD) de yine üç farklı hücre basıncı ve iki farklı konsolidasyon süresinde gerçekleştirilmiştir. Elde edilen sonuçlar Şekil 6-11'de sunulmaktadır.
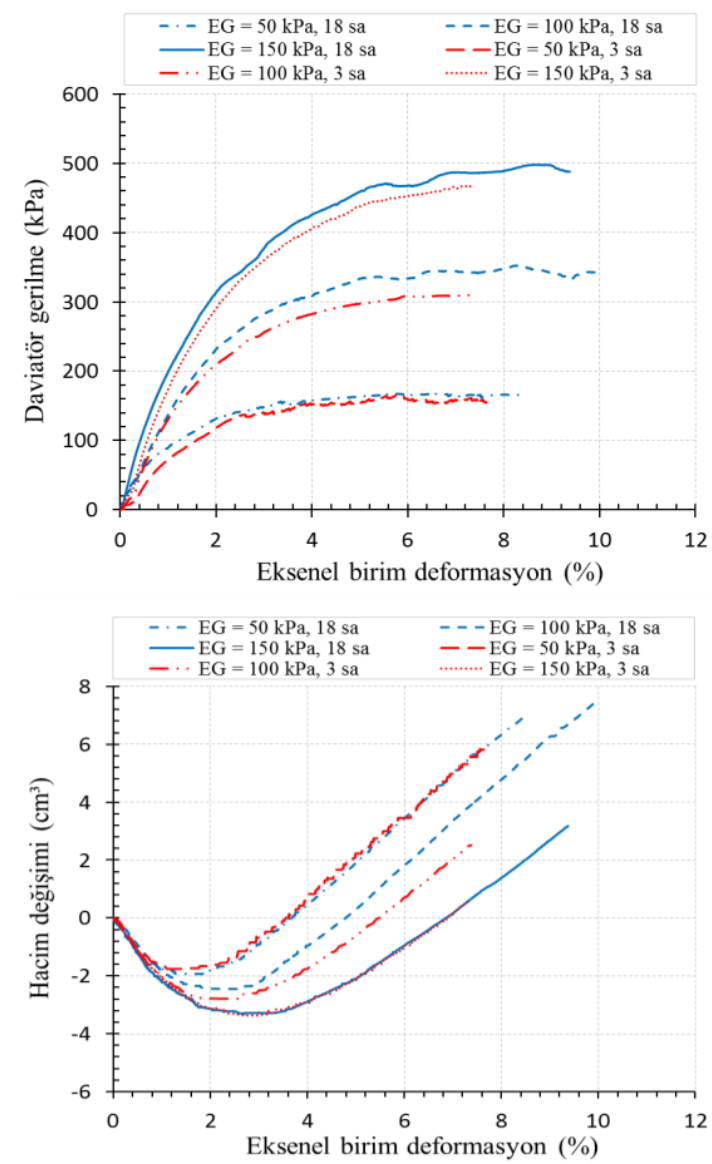

Şekil 6. CD deney koşullarında 3 ve 18 saat konsolidasyon sürelerinde test edilen Narlı kumuna ait (a) gerilme-şekil değiştirme eğrisi (b) boşluk suyu basıncıeksenel birim deformasyon eğrisi 
Genel olarak, ölçüm yapılan aralıkta deviatörik gerilmenin eksenel yer değiştirme ile arttı̆̆ gözlemlenmiştir. Deviatörik gerilme ve hacim değişimi efektif gerilmeden önemli ölçüde etkilenmekle birlikte konsolidasyon süresindeki değişimden çok fazla (yaklaşık ortalama \%5) etkilenmemiştir. Farklı hücre basıncı ve farklı konsolidasyon sürelerinde test edilen örneklere ait gerilme izi sonuçları karşılaştırılmalı olarak Şekil 7'de sunulmaktadır. Farklı efektif gerilmeler altında test edilen temiz kum örneklerine ait gerilme izi şekilleri konsolidasyon süresinin değişiminden etkilenmemiştir. Çünkü, bu grup deneyler drenajlı olarak yapılmıştır.

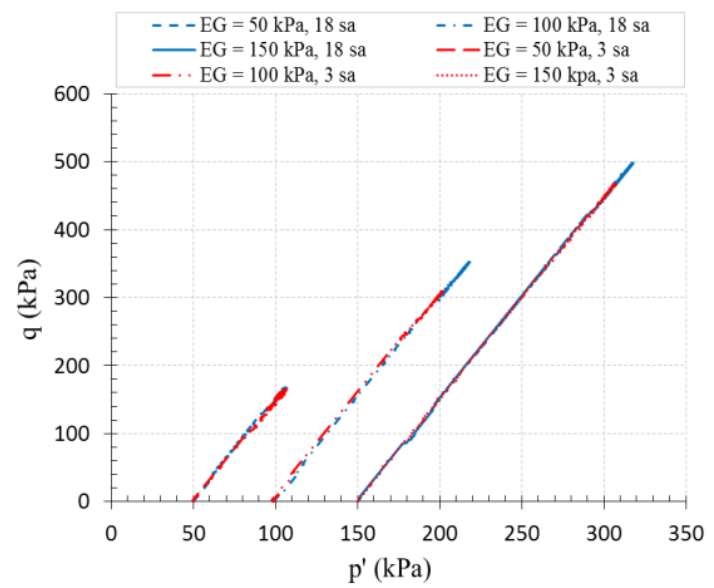

Şekil 7. CD deney koşullarında 3 ve 18 saat konsolidasyon sürelerinde test edilen Narlı kumuna ait gerilme izi

Şekil 8'de CD koşullarında tamamlanan deney serisi için eksenel şekil değiştirme ile zeminin rijitliğindeki azalma eğilimi sunulmaktadır. Drenajlı koşuldaki zemin rijitliği, özellikle düşük şekil değiştirme seviyelerinde yüksek değerlerdedir, ve hücre basıncı ile konsolidasyon süresinden önemli derecede etkilendiği gözlemlenmiştir. Diğer taraftan, kesme sırasında hücre basıncı azaldıkça ve eksenel şekil değiştirme artıkça, hücre basıncı ve konsolidasyon süresinin etkisi azalmaktadır. Bu deneylere ait eksenel şekil değiştirme ve hacim değişimi ilişskisi Şekil 9'da gösterilmektedir. Küçük eksenel şekil değiştirme değerlerinde ulaşılan hacimsel değişim oranı değerleri her iki konsolidasyon süresi için büyük benzerlik gösterirken, elde edilen değerler arasındaki farklılık daha büyük eksenel şekil değiştirme değerlerinde artmıştır. Hacimsel değişim oranı miktarı, uygulanan yüksek efektif gerilme değerlerinde $(150 \mathrm{kPa})$ düşük efektif gerilme değerlerine $(50 \mathrm{kPa})$ göre çok daha fazla olmuştur. Ayrıca kesme sırasında, ortalama efektif gerilme-özgül hacim ilişkisi efektif gerilme değişiminden önemli derecede etkilenmesine rağmen konsolidasyon süresindeki değişiminden çok fazla etkilenmemiştir (Şekil 10).

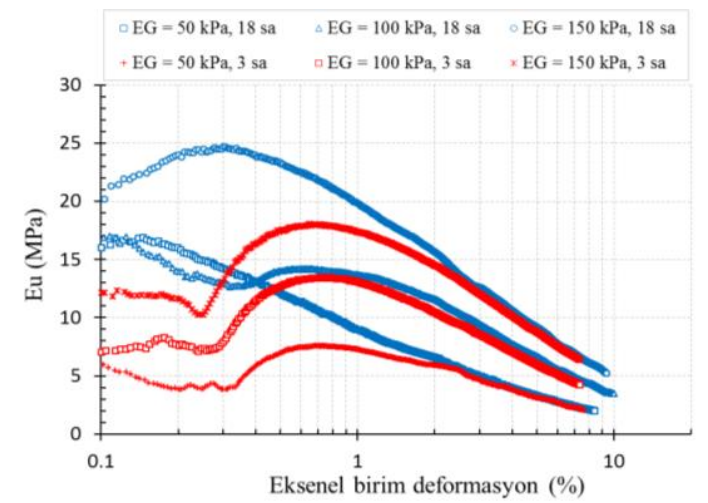

Şekil 8. CD deney koşullarında 3 ve 18 saat konsolidasyon sürelerinde test edilen Narlı kumuna ait elsatisite modülü değerlerinin karşılaştırılması

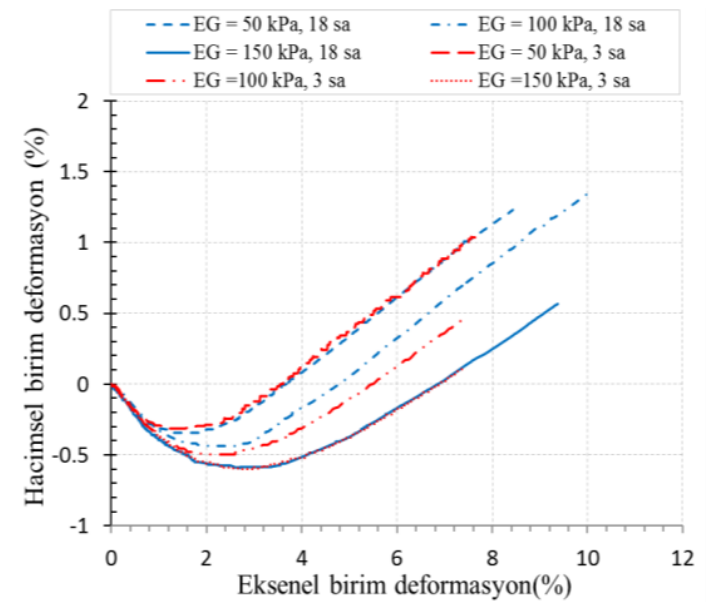

Şekil 9. CD deney koşullarında 3 ve 18 saat konsolidasyon sürelerinde test edilen Narlı kumuna ait eksenel birim deformasyon ile birlikte hacim değişimi 


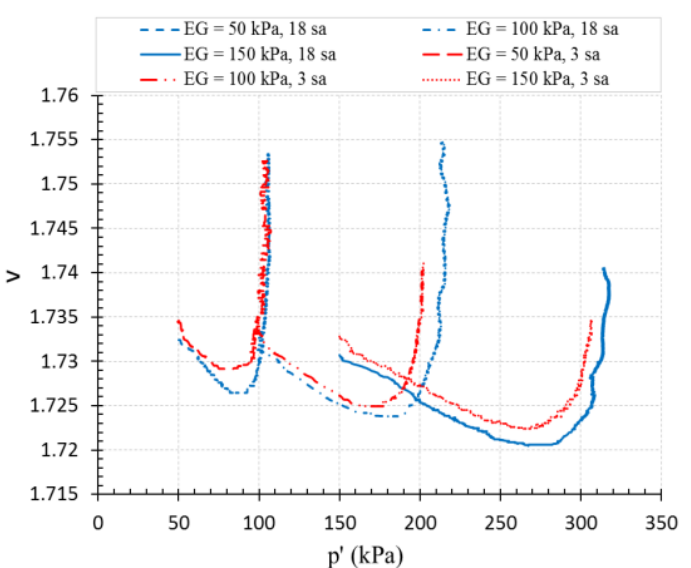

Şekil 10. CD deney koşullarında 3 ve 18 saat konsolidasyon sürelerinde test edilen Narlı kumuna ait ortalama efektif gerilme ile hacim değişimi

18 saatlik konsolidasyon süresi sonunda test edilen (CU ve $\mathrm{CD}$ ) kum örneklerine ait gerilme-şekil değiştirme ilişkisi Şekil 11'de sunulmaktadır.

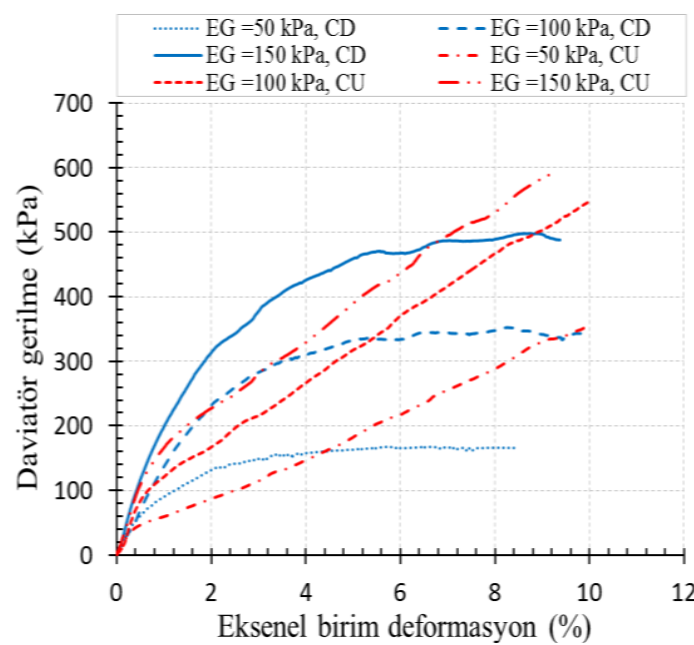

Şekil 11. CU ve CD deney koşullarında 18 saat konsolidasyon süresinde Narlı kumuna ait gerilme- eksenel birim deformasyon davranışı

Görüldüğü üzere, drenajlı koşulda (CD) test edilen kum örneklerinin düşük şekil değiştirme seviyelerindeki deviatörik gerilme değerleri drenajsız koşulda (CU) elde edilenlere göre çok daha büyüktür. Bu durum uygulanan tüm efektif gerilme değerlerinde aynı şekilde gözlemlenmiştir. Park ve Jeong [22]'1n işaret ettiği gibi drenajlı koşullarda elde edilen deviatörik gerilme değerleri drenajsız koşularda elde edilen değerlere göre daha fazladır. Drenajlı test koşullarındaki bu davranışın nedeninin kademeli zemin sertleşmesi olduğu düşünülmektedir. Drenajlı ve drenajsız koşullarda test edilen Narlı Kumu örneklerine ait gerilme izi verileri Şekil 12'de kıyaslamalı olarak sunulmaktadır.

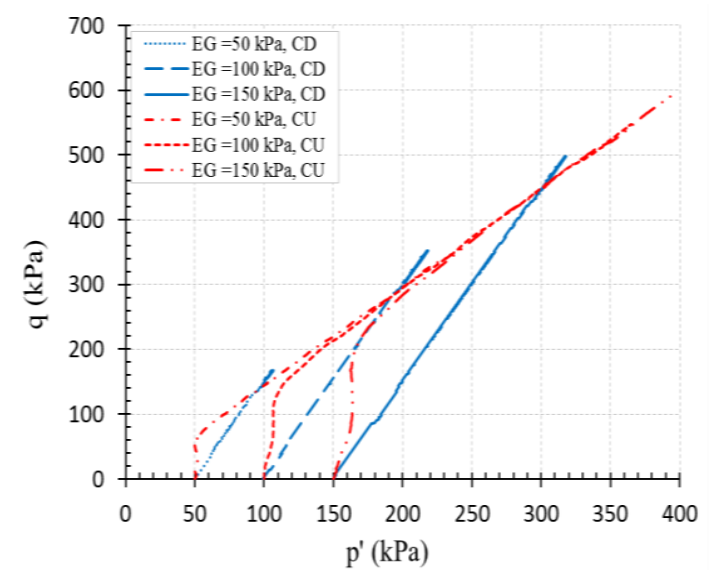

Şekil 12. CU ve CD deney koşullarında 18 saat konsolidasyon sürelerinde Narlı kumuna ait gerilme izi değişimi

Uygulanan tüm efektif gerilme değerleri için, drenajsız koşullarda (CU) test edilen örneklerde gözlemlenen hacimsel azalma (contraction) davranışı drenajlı koşullarda (CD) test edilen örneklere kıyasla çok daha net olarak gözlemlenmiştir. Yazarlar, bu davranışın nedeni olarak deneyin başlangıç aşamasında oluşan pozitif aşırı boşluk suyu basıncını düşünmektedirler. Şekil 13, drenajlı ve drenajsız koşullarda yapılan deneylerde tespit edilen eksenel şekil değiştirme ile zemin rijitliği azalmasındaki ilişkiyi göstermektedir. Uygulanan tüm efektif gerilme değerlerinde tespit edilen rijitlik değerleri drenajlı koşullarda test edilen örneklerde drenajsız koşulda test edilenlere göre her zaman daha yüksek olmuştur. Ancak, eksenel şekil değiştirme oranı arttıkça rijitlik değerlerinin birbirlerine yaklaştığ1 görülmektedir. $\mathrm{Bu}$ davranış, zemin daneleri arasındaki sürtünmeyi azaltan aşırı boşluk suyu basıncı oluşumundan kaynaklanmaktadır. 


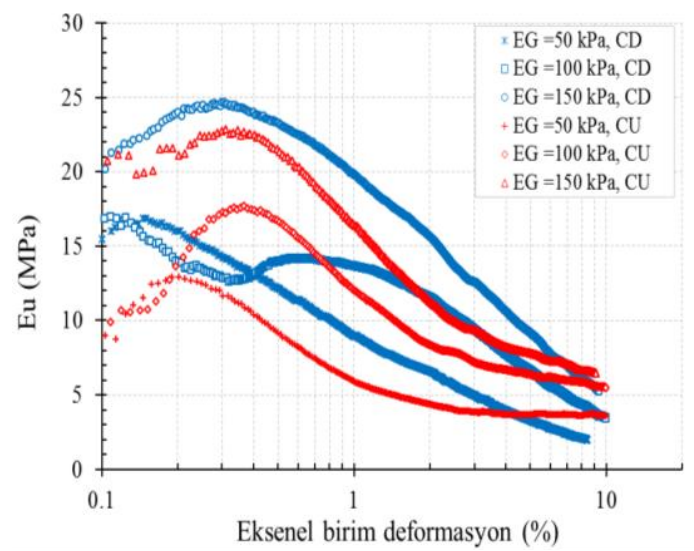

Şekil 13. CU ve CD deney koşullarında 18 saat konsolidasyon süresinde Narlı kumuna ait elastisite modüllerinin eksenel birim deformasyon ile azalması

Gevşek sıkılıkta hazırlanan temiz Narlı Kumu örneklerinin üç eksenli deneylerde elde edilen Mohr dairesi ve kırılma zarfları Şekil 14-17'de sunulmaktadır.

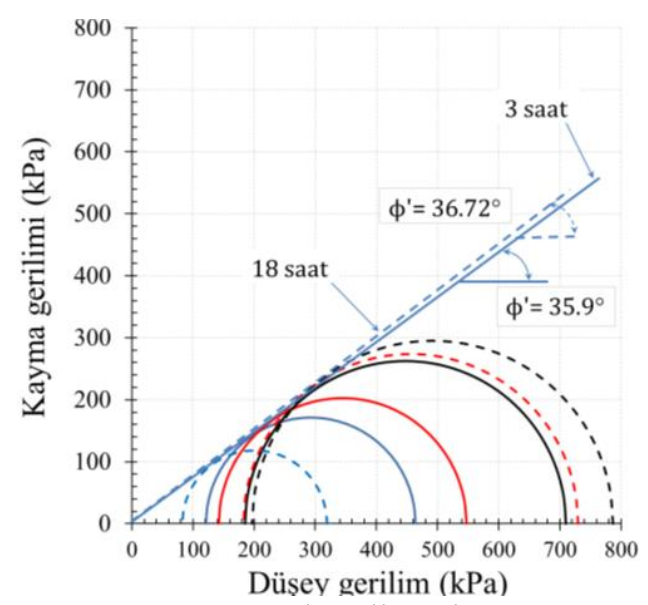

Şekil 14. CU deney koşullarında konsolidasyon süresinin kırılma zarfina olan etkisi (Efektif gerilme).

Drenajsız koşullarda (CU) test edilen örneklere ait kırılma zarfi ve içsel sürtünme açısı değerleri efektif gerilmeye bağlı olarak tespit edilmiştir (Şekil 14). Görüleceği üzere, kohezyonu olmayan bu zeminlerde uygulanan konsolidasyon süresinin, kırılma zarfı ve içsel sürtünme açısı değerlerine etkisi oldukça sınırlı kalmıştır (yaklaşık \%2).
Şekil 15 'de drenajlı deney koşullarında yapılan testlerde ulaşılan kırılma zarfi ve içsel sürtünme açısı değerleri efektif gerilmeye bağlı olarak sunulmaktadır.

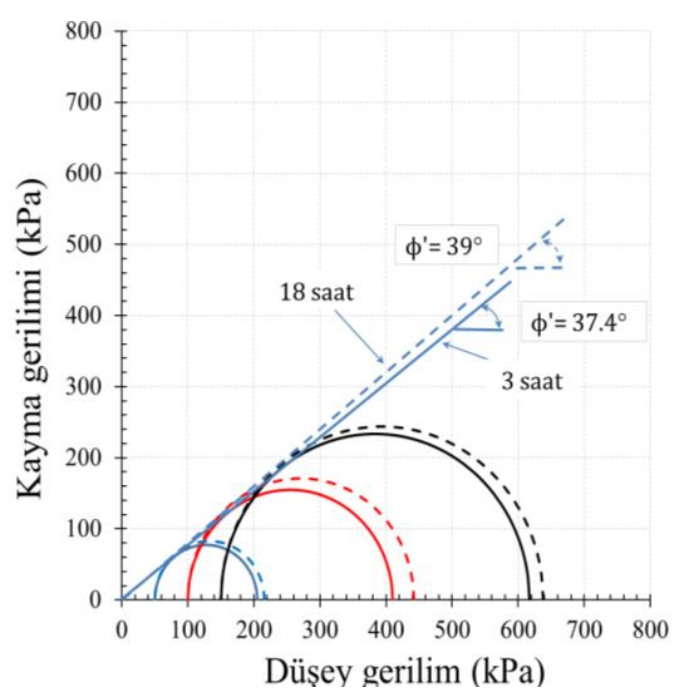

Şekil 15. CD deney koşullarında konsolidasyon süresinin kırılma zarfina olan etkisi (Efektif gerilme)

Elde edilen bu sonuçlar 1şı̆̆ında, 3 saat ve 18 saat konsolidasyon süreleri sonunda tespit edilen içsel sürtünme açısı değerleri arasında çok küçük bir fark olduğu görülmüştür (yaklaşık \%4). Drenajlı ve drenajssz deneylerden elde edilen Mohr dairesi, kırılma zarfı ve içsel sürtünme açısı değerleri karşılaştırmalı olarak Şekil 16-17'de gösterilmektedir. Her iki konsolidasyon periyodu (3 saat ve 18 saat) için, drenajlı testlerde belirlenen içsel sürtünme açısı değerleri drenajsız testlerde berlirlenen değerlerinde her zaman yaklaşık $\% 4$ oranında daha büyük tespit edilmiştir. Bu durum, drenajsız deney koşularında oluşan aşırı boşluk suyu basıncına işaret etmektedir.

Rölatif sıkılığın drenajsız koşullarda tamamlanan deney sonuçlarına etkisini araştırmak için üç farklı rölatif sıkılık değerinde hazırlanan zeminler test edilmiştir. $\mathrm{Bu}$ değerler, gevşek, orta ve sik1 durumları temsil eden $\% 35, \% 63$ ve $\% 85$ olarak belirlenmiştir [24]. Deneyler, $100 \mathrm{kPa}$ efektif gerilme altında 3 saat veya 18 saat bekletildikten sonra tamamlanmıştır. 


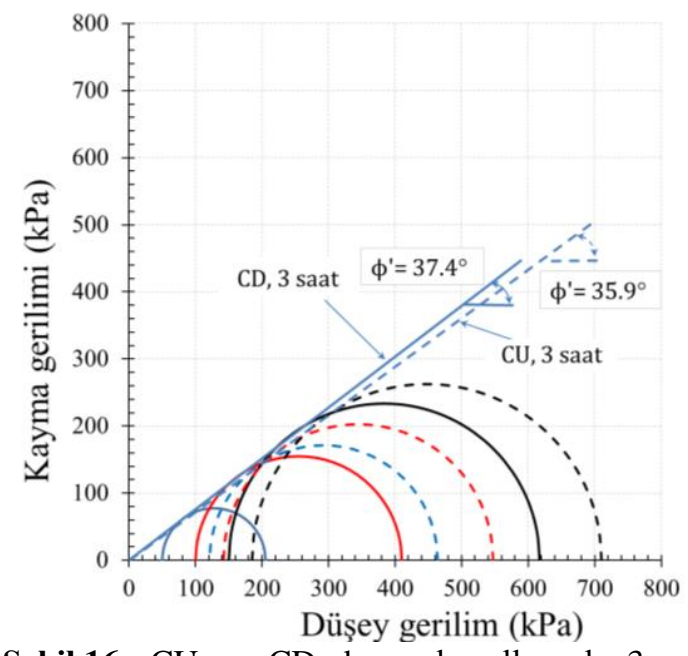

Şekil 16. $\mathrm{CU}$ ve $\mathrm{CD}$ deney koşullarında 3 saat konsolidasyon süresinde Narlı kumuna ait kırılma zarfları (Efektif gerilme)

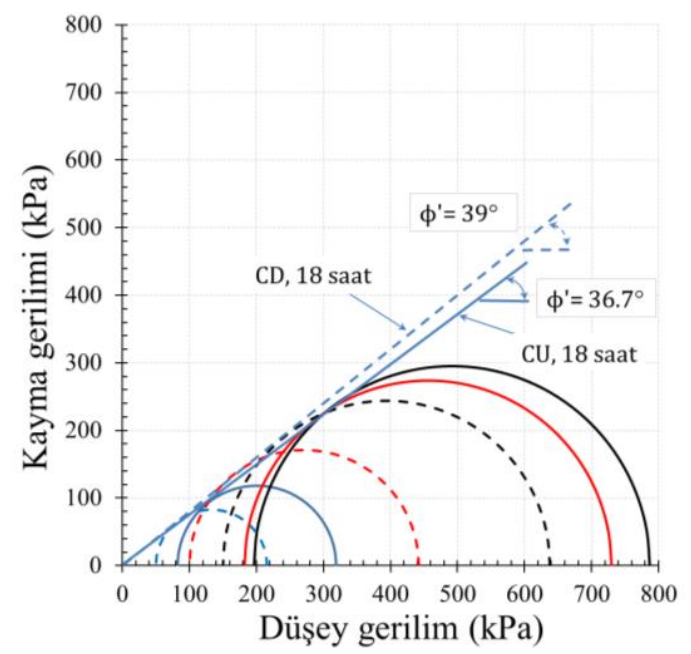

Şekil 17. CU ve CD deney koşullarında 18 saat konsolidasyon süresinde Narlı kumuna ait kırılma zarfları (Efektif gerilme)

Şekil 18 deviatörik gerilme ve boşluk suyu basıncının şekil değiştirme ile ilişkisini göstermektedir. Rölatif sıkılık arttığında deviatörik gerilme değerlerinde $\% 10$ ile $\% 30$ arasındaki oranlarda artış, boşluk suyu basıncı değerlerinde ise $\% 5$ ile $\% 10$ arasındaki oranlarda azalma gözlemlenmiş̧tir. $\mathrm{Bu}$ durum, kum daneleri arasındaki sürtünme mukavemetinin ( $(\tan \varphi$ ') artışına neden olan daneler arasındaki temas yüzeyi artışından dolayı olmuştur. Ayrıca yüksek rölatif sıkılık, kum daneleri arasındaki kenetlenmenin artmasına neden olabilir. Ismail ve arkadaşları [25] tarafından işaret edildiği gibi daneler arası temas yüzeyi ve kenetlenme zeminin rölatif sıkılığı ile doğrudan ilişkilidir.
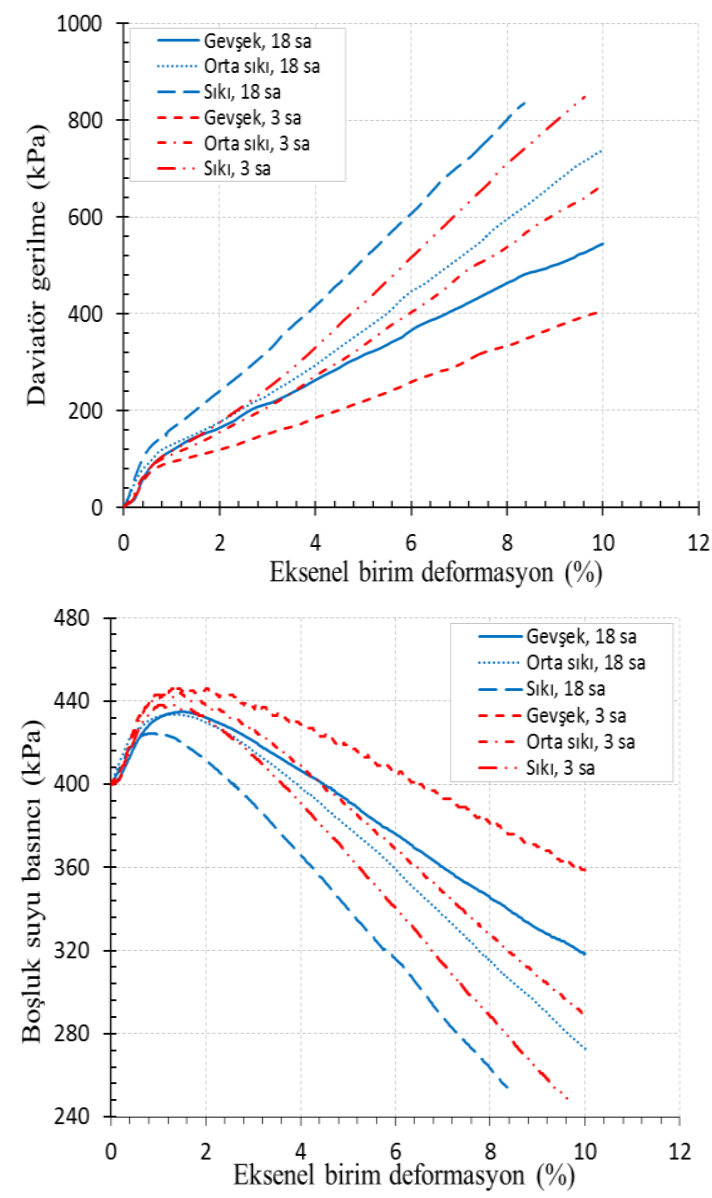

Şekil 18. CU deney koşullarında 3 ve 18 saat konsolidasyon sürelerinde Narlı kumuna ait(a) gerilme-eksenel birim deformasyon davranışının rölatif sıkılık ile değişimi (b) boşluk suyu basıncının rölatif sıkılık ile değişimi

Farklı rölatif s1kılıklarda hazırlanan örneklere ait gerilme izi grafikleri Şekil 19'da gösterilmektedir. Her iki konsolidasyon süresi için, test edilen örneklerin rölatif sıkıllı̆ı arttıkça hacim azalmasının (contraction) da arttığı görülmüştür. 
$\mathrm{Bu}$ davranışın nedeni olarak artan rölatif sıkılık değerleri ile birlikte oluşan daha yüksek boşluk suyu basıncı olduğu düşünülmektedir. Şekil 20 farklı rölatif sıkılık değerlerinde test edilen örneklerde elde edilen eksenel şekil değiştirmerijitlik azalması grafiğini göstermektedir. Rölatif sıkılık arttıkça malzemenin rijitliği de artmaktadır ve bu davranış her iki konsolidasyon süresi için de aynı şekilde gözlemlenmiştir. Benzer bir davranış gösteren deviatörik gerilme değişimi ise daneler arasındaki sürtünme ve kenetlenme ile ilişkilidir.

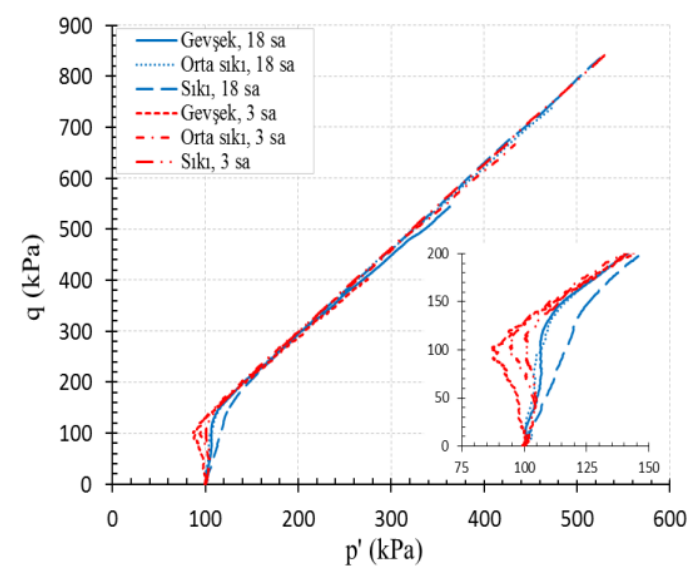

Şekil 19. CU deney koşullarında 3 ve 18 saat konsolidasyon sürelerinde Narlı kumunda ait rölatif sıkılığın gerilme izine etkisi

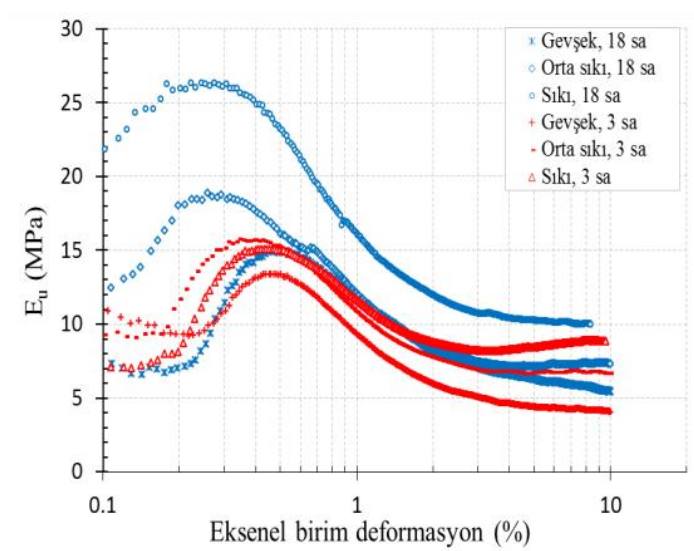

Şekil 20. CU deney koşullarında 3 ve 18 saat konsolidasyon sürelerinde Narlı kumunda rölatif sıkılığın elastisite modulü azalmasına etkisi

\section{SONUÇLAR}

Bu çalışmanın amacı, son yıllarda artan nüfus ve gelişen ekonomiden dolayı Güneydoğu Anadolu Bölgesi'nin batısındaki (Adana, Gaziantep, Antakya, Mersin, Kahramanmaraş, Osmaniye, Kilis) geoteknik çalışmalarda yoğunlukla kullanılan Narlı Kumunun kayma davranışını üç eksenli basınç deneyleri kullanarak araştırmaktır. Efektif gerilme, konsolidasyon süresi, drenaj durumu, ve rölatif sıkılık parametrelerinin Narlı Kumu üzerindeki etkilerinin incelendiği laboratuar çalışmalarında ulaşılan sonuçlar aşağıdaki gibi siralanabilir.

- Genel olarak bakıldığında, yapılan tüm deneylerde (CU, CD), temiz kum örneklerine ait deviatörik gerilme ve rijitlik değerleri, artan efektif gerilme ve konsolidasyon süresine bağlı olarak artmıştır. Drenajsız (CU) testlerdeki boşluk suyu basıncı oluşumu efektif gerilme ve konsolidasyon süresiyle artmıştır. Uygulanan efektif gerilmedeki artışa bağlı olarak hacimsel değişimde artış gözlemlenmiştir.

- Konsolidasyon süresi azaldıkça Narlı Kumu örnekleri daha fazla hacimsel azalma (contraction) davranışı göstermiştir. Hücre basıncındaki değişim ise aynı örneklerin hacimsel azalma (contraction) ve hacimsel ayrışma (dilatation) özellikleri üzerinde etkili olmamıştır.

- Narlı Kumu üzerinde yapılan drenajlı deneylerde elde edilen deviatörik gerilme, rijitlik, ve içsel sürtünme açısı değerleri drenajsiz deneylerde elde edilenlerden daha yüksektir. Ayrıca, tüm efektif gerilme değerleri için, drenajsız koşulda test edilen zemin örnekleri, drenajlı koşulda test edilen örneklere göre daha fazla hacimsel azalma (contraction) sergilemiştir.

- Narlı kum örnelerine ait rölatif sıkılık değerlerindeki artış deviatörik gerilme ve rijitlik değerlerini artırırken, oluşan aşırı boşluk suyu basıncında azalma olduğu görülmüştür. Aynı konsolidasyon süresinde bekletildikten sonra test edilen örnekler için, rölatif sıkılık arttıça kum örneklerinin hacimsel azalma (contraction) eğiliminde artış olmuştur. 
Burada sunulan deneysel çalışmalar sonucunda test koşullarına bağlı olarak $35,9^{\circ}$ ile $39^{\circ}$ arasında değişen içsel sürtünme açısı $(\varphi)$ değerlerine sahip olan temiz Narlı Kumu örneklerinin dinamik özelliklerinin tespit edilmesi, geoteknik çalışmalarda yoğunlukla kullanılan bu zemin malzemesinin altyapı faaliyetlerinde güvenli olarak uygulanabilmesi için gereklidir.

\section{KAYNAKLAR}

1. Coulomb, C.A., 1776. Essai Sur une Application des Regles des Maximis et Minimis a Quelques Problemes des Statique Relatifs a L'Architecture, Mem. Acad. R. Pres. Divers Savants, 7, Paris.

2. Lee K.L., Seed H.D., 1967. Drained Characteristics of Sand, Journal of the Soil Mech. and Found. Div., ASCE, 93(SM6).

3. Ahmed, S.N.U., 1972. A Study of the Influence of Confining Pressure on the Behavior of Sands, PhD Thesis, McGill university, Montreal, P.Q.

4. Kramer, S.L., Seed, H.B., 1988. Initiation of Soil Liquefaction under Static Loading Conditions, Journal of Geotechnical Engineering, 114(4), 412-430.

5. Cuccovillo, T., Coop, M.R., 1997. The Measurement of Local Axial Strains in Triaxial Tests using LVDTs, Géotechnique, 47(1).

6. Della, N., Arab, A., Belkhatir, M., 2001. Effect of Confining Pressure and Depositional Method on the Undrained Shearing Response of Medium Dense Sand, Journal of Iberian Geology, 37(1), 37-44.

7. Sayeed, A.M., Suzuki, K., Rahman, M.M., 2011. Strength and Deformation Characteristics of Granular Materials under Extremely Low to High Confining Pressures in Triaxial Compression, International Journal of Civil and Environmental Engineering, 11(4), 1-6.

8. Clayton, C.R.I., Heymann, G., 2001. Stiffness of Geomaterials at Very Small Strains, Géotechnique, 51(3), 245-255.

9. Tsomokos, A., Georgiannou, V.N., 2010. Effect of Grain Shape and Angularity on the Undrained Response of Fine Sands, Canadian Geotechnical Journal, 47(5), 539-551.
10. Shahnazari, H., Salehzadeh, H., Rezvani, R., 2014. The Effect of Shape and Stiffness of Originally Different Marine Soil Grains on Their Contractive and Dilative Beaviour, KSCE Journal of Civil Engineering, 18(4), 975-983.

11. Bayat, E., Bayat, M., 2013. Effect of Grading Characteristics on the Undrained Shear Strength of Sand: Review with New Evidences, Arabian Journal of Geosciences, 6 (11), 4409-4418.

12. Belkhatir, M., Schanz, T., Arab, A., 2013. Effect of Fines Content and Void Ratio on the Saturated Hydraulic Conductivity and Undrained Shear Strength of Sand-Silt Mixtures, Environmental Earth Sciences, 70 (6), 2469-2479.

13. Belkhatir, M., Schanz, T., Arab, A., 2014. Insight into the Effects of Gradation on the Pore Pressure Generation of Sand-Silt Mixtures, Geotechnical Testing Journal, 37(5), 922-931.

14. Porovic, E., Jardine, R.J., 1994. Some Observations on the Static and Dynamic Shear Stiffness of Ham River Sand. In Proceedings of the international symposium on Pre-failure Deformation Characteristics of Geomaterials, Sapporo, 25-30.

15. Viggiani, G., Atkinson, J.H., 1995. Stiffness of Fine-Grained Soil at Very Small Strains, Géotechnique, 45(2), 249-265.

16. Maeda, K., Miura, K., 1999. Relative Density Dependency of Mechanical Properties of Sands. Soils and Foundations, 39(1), 69-79.

17. Kokusho T., Hara T., Hiraoka R., 2004. Undrained Shear Strength of Granular Soils with Different Particle Gradations, Journal of Geotechnical and Geoenvironmental Engineering, 130(6), 621-629.

18. Della N., Belkhatir M., Arab A., 2015. Undrained Monotonic Response and Instability of Medium-Dense Sandy Soil, Marine Geosources \& Geotechnology, 33 (6), 487-495.

19. Thevanayagam, S., 1998. Effect of Fines and Confining Stress on Undrained Shear Strength of Silty Sands, Journal of Geotechnical and Geoenvironmental Engineering, 124(6), 479-491. 
20. Cabalar, A.F., Dulundu, K., Tuncay, K., 2013. Strength of Various Sands in Triaxial and Cyclic Direct Shear Tests. Engineering Geology, 156, 92-102.

21. Yao, Y.P., Sun, D.A., Luo, T., 2004. A Critical State Model for Sands Dependent on Stress and Density, International Journal for Numerical and Analytical Methods in Geomechanics, 28(4), 323-337.

22. Park, S.S., Jeong, S.W., 2015. Effect of Specimen Size on Undrained and Drained Shear Strength of Sand, Marine Geosources \& Geotechnology, 33(4), 353-358.

23. Skempton, A.W., 1954. The Pore Pressure Coefficients A and B, Geotechnique, 4(4), 143-147.

24. Terzaghi, K., Peck, R.B., Mesri, G., 1996. Soil Mechanics in Engineering Practice, John Wiley \& Sons, Inc. Third Edition, Printed in the United States of America.

25. Ismail, M.A., Joer, H.A., Sim, W.H., Randolph, M.F., 2002. Effect of Cement Type on Shear Behavior of Cemented Calcareous Soil, Journal of Geotechnical and Geoenvironmental Engineering, 128(6), 520529. 